Institute of Technology

Term expiring February 12, 1992: James Thurber, American University

American Association for the Advancement of Slavic Studies (AAASS)

Charles Gati, Columbia University

American Council of Leamed Societies (ACLS)

Theodore J. Lowi, Cornell University

Consortium of Social Science Associations (COSSA)

Terms expiring December 31, 1993: Raymond E. Wolfinger, University of California, Berkeley

Catherine E. Rudder, American Political

Science Association

Council of Professional Association on Federal Statistics (COPAFS)

Howard Silver, COSSA

Jack Katosh, Mathew Greenwald \& Associates

International Political Science Association (IPSA)

Terms expiring 1995:

Theodore J. Lowi, Cornell University

Walter Dean Burnham, University of Texas

Catherine E. Rudder, American Political

Science Association

Social Science Research Council (SSRC)

Term expiring June 30, 1992:

Suzanne Berger, Massachusetts Institute of Technology

\section{A Report on the Congressional Fellowship Program, 1990-91 and 1991-92}

The Congressional Fellowship Program is a professional level internship that gives academics, journalists, federal executives, and other professionals an opportunity to work on the staffs of senators, representatives, and congressional committees. Its goals are:

- to improve the quality of scholarship and teaching on Congress and American national politics;

- to enhance public understanding of Congress and policymaking; and

- to provide professionals from several fields with practical experience in Congress and insight into the legislative process.
Since 1953, the first year of the Program, there have been a total of 1,442 Fellows, including 229 political scientists, 188 journalists, 702 federal executives, 290 medical faculty, and others.

Although the first class of Fellows had only six members, in recent years the Program has grown to include between 40 and 50 Fellows each year. The political science and journalism Fellows are selected in nationwide competitions. Political science applicants must have completed their doctorates within the last fifteen years or be near completion, and reporters must have a bachelor's degree and between two and ten years of professional experience in newspaper, magazine, television, or radio reporting. Criteria for selection are quality training, demonstrated competence, maturity and responsibility, relevance of fellowship experience to career goals, and potential for professional advancement.

While the political scientists and journalists remain the core of the program and are supported by the APSA through contributions from corporations and foundations, the majority of each year's class of Fellows participates in the program through affiliate arrangements, including:

- federal executives (Grades 13-16) supported by agency training funds;

- Asian Fellows supported by the Asia Foundation;

- Health Policy Fellows, including medical faculty, supported by the Robert Wood Johnson Foundation;

- anthropology faculty supported by the American Anthropological Association;

- German Fellows supported by The German Marshall Fund;

- Carl Albert Fellows supported by the Carl Albert Center at the University of Oklahoma; and

- a French Fellow supported by the Fondation Franco-Americaine in Paris.

In recent years, those who have funded political scientists and journalists include the Knight Foundation, Knight Ridder, Incorporated, the Mary Norris Preyer Fund, the New York Times Company Foundation, MCI Communications Corporation, International Business Machines and the Poynter Fund.

The Walter and Phyllis Shorenstein family has provided funding to endow a Fellowship in the name of their daughter, Joan Shorenstein Barone. Joan was a well-known and highly respected producer for CBS News who died in 1985 at a tragically early age. The Joan Shorenstein Barone Fellowship is awarded annually to a broadcast journalist of special merit, and was given for the first time to a
1986-87 Fellow, Jean Powell, news reporter for KEZI-TV in Eugene, Oregon. Heather Greenfield, reporter for WCIV-TV, Charleston, South Carolina, has been named the 1991-92 Joan Shorenstein Barone Congressional Fellow.

The Poynter Fund contribution is designated to support a promising Fellow in print journalism. The first Poynter Fellow was Celia Chen (1985-86), staff reporter for the Wilmington, Delaware News-Journal. The 1991-92 Poynter Fellow is Claude R. Marx, political reporter, Arkansas Democrat, Little Rock.

In early 1991, MCI Communications Corporation awarded the Association a generous endowment to support the Congressional Fellowship Program in perpetuity. In addition to funding six political scientists and journalists, the gift provides financial support for two scholars from any field or discipline, or journalists, all of whom must have an analytical interest in public policy and in telecommunications. The APSA-MCI Communications Fellows are chosen annually through rigorous national competition and the first APSA-MCI Communications Fellows will be selected from among candidates competing for 1992-93 Congressional Fellowships.

The Fellowship Program commences in early November with an orientation period that includes meetings and seminars with members of Congress, congressional staffs, political scientists, journalists, lobbyists, government administrators, and others on a wide range of topics relating to Congress and national politics. During this time Fellows also begin exploring possibilities for assignments in congressional offices. These negotiations are conducted by the Fellows themselves, and their placements are decided by the Fellows and the offices in which they will work. Fellows begin work in House or Senate offices in early December, and serve in their initial assignments for about four and one-half months. In April they are encouraged to seek new assignments on the other side of the legislature so that each Fellow has an opportunity to experience both the House and Senate during the Fellowship year. Seminars for the Fellows are held throughout the year to supplement the orientation period, and each Fellow also makes one trip with a Senator or Representative to the member's home state or district to observe constituent work and campaign activities.

Kay Sterling is Administrative Director of the Congressional Fellowship Program. Christopher J. Deering, Associate Dean, Columbian College, The George Washington University, is Director for Academic Planning and Development. An Advisory Committee, whose members are 
listed below, provides overall policy guidance for the Program.

\section{Congressional Fellowship Program Advisory Committee}

Thomas E. Mann, The Brookings Institution, Chairman

Michael Barone, U.S. News \& World Report

David S. Broder, The Washington Post

The Honorable Robert Dole, Minority Leader of the Senate

Eugene Eidenberg, MCI Communications Corporation

The Honorable Thomas Foley, Speaker of the House

The Honorable Bill Frenzel, The Brookings Institution

David R. Gergen, U.S. News \& World Report

Albert R. Hunt, Wall Street Journal

Gerald J. Kovach, MCI Communications Corporation

The Honorable Richard Lugar, United States Senate

Philip Meyer, University of North Carolina

Norman J. Ornstein, American Enterprise Institute

Leonard Parkinson, Atlantic Research Corporation

The Honorable Richardson Preyer, Greensboro, NC

The Honorable David Price, United States House of Representatives

Cokie Roberts, National Public Radio

Robert M. Rosenzweig, Association of American Universities

The Honorable Paul Simon, United States Senate

Barbara Sinclair, University of California-Riverside

Neil Skene, Congressional Quarterly Weekly Report

Charles E. Walker, Charles E. Walker Associates

The Honorable Vin Weber, United States House of Representatives

Eddie N. Williams, Joint Center for Political Studies

\section{Seminar Speakers and}

\section{Related Activities, 1990-91}

Annapolis, a day-long review of one model (Maryland) of state government. Participants included: Donald Norris, Director, Institute for Policy Analysis and Research, University of Maryland; The Honorable Clarence Blount, Majority Leader, Maryland State Senate; John Frece, Annapolis Bureau Chief, Baltimore Sun; The Honorable Jacqueline $\mathrm{H}$. Rogers, Secretary, Department of Housing and Community Development; The Honorable Nancy Kopp, Speaker Pro Tempore of the House of Delegates; The Honorable Thomas Mike Miller, Presi-

\begin{tabular}{|c|c|c|c|c|c|c|}
\hline Year & $\begin{array}{l}\text { Political } \\
\text { Scientists }\end{array}$ & Journalists & $\begin{array}{c}\text { Total } \\
\text { Federal }\end{array}$ & $\begin{array}{c}\text { Federal/ } \\
\text { Foreign } \\
\text { Affairs }\end{array}$ & Other* & TOTAL \\
\hline $1953-54$ & 5 & 1 & & & & 6 \\
\hline $1954-55$ & 4 & 5 & & & 1 & 10 \\
\hline $1955-56$ & 5 & 5 & & & & 10 \\
\hline $1956-57$ & 4 & 6 & & & 1 & 11 \\
\hline $1957-58$ & 10 & 5 & & & & 15 \\
\hline $1958-59$ & 8 & 6 & & & 3 & 17 \\
\hline $1959-60$ & 8 & 7 & & & 5 & 20 \\
\hline $1960-61$ & 8 & 7 & & & 7 & 22 \\
\hline 1961-62 & 9 & 5 & 5 & & 4 & 24 \\
\hline $1962-63$ & 7 & 8 & 9 & & 6 & 30 \\
\hline 1963-64 & 8 & 7 & 7 & & 6 & 28 \\
\hline $1964-65$ & 8 & 7 & 11 & & 3 & 29 \\
\hline $1965-66$ & 7 & 6 & 17 & & 9 & 39 \\
\hline $1966-67$ & 5 & 7 & 22 & & 7 & 41 \\
\hline $1967-68$ & 10 & 6 & 23 & & 7 & 46 \\
\hline $1968-69$ & 7 & 9 & 24 & & 7 & 47 \\
\hline $1969-70$ & 11 & 5 & 24 & & 5 & 45 \\
\hline $1970-71$ & 8 & 8 & 18 & & 5 & 39 \\
\hline $1971-72$ & 8 & 8 & 27 & $20 / 7$ & 5 & 48 \\
\hline $1972-73$ & 8 & 5 & 26 & $17 / 10$ & 4 & 44 \\
\hline $1973-74$ & 6 & 7 & 26 & $16 / 10$ & 3 & 42 \\
\hline $1974-75$ & 7 & 5 & 27 & $16 / 11$ & 10 & 49 \\
\hline $1975-76$ & 7 & & 27 & $17 / 10$ & 9 & 43 \\
\hline $1976-77$ & 5 & 3 & 28 & $17 / 11$ & 10 & 46 \\
\hline $1977-78$ & 6 & 2 & 27 & $18 / 9$ & 12 & 47 \\
\hline $1978-79$ & 4 & 4 & 28 & $17 / 11$ & 10 & 46 \\
\hline $1979-80$ & 3 & 2 & 30 & $19 / 11$ & 9 & 44 \\
\hline $1980-81$ & 2 & 4 & 21 & $11 / 10$ & 12 & 39 \\
\hline $1981-82$ & 4 & 4 & 28 & $17 / 11$ & 14 & 50 \\
\hline $1982-83$ & 3 & 3 & 27 & $15 / 12$ & 14 & 47 \\
\hline 1983-84 & 5 & 2 & 27 & $15 / 12$ & 13 & 47 \\
\hline $1984-85$ & 4 & 3 & 26 & $14 / 12$ & 15 & 48 \\
\hline $1985-86$ & 4 & 2 & 25 & $15 / 10$ & 16 & 47 \\
\hline $1986-87$ & 4 & 4 & 23 & $12 / 11$ & 14 & 45 \\
\hline $1987-88$ & 3 & 4 & 22 & $10 / 12$ & 19 & 48 \\
\hline $1988-89$ & 3 & 3 & 24 & $13 / 11$ & 14 & 44 \\
\hline $1989-90$ & 3 & 4 & 25 & $14 / 11$ & 17 & 49 \\
\hline $1990-91$ & 3 & 4 & 24 & $13 / 11$ & 14 & 45 \\
\hline $1991-92$ & 4 & 4 & 24 & $14 / 10$ & 13 & 45 \\
\hline
\end{tabular}

dent, Maryland Senate; William S. Ratchford III, Director, Department of Fiscal Services

John E. Chubb, Senior Fellow, The Brookings Institution, "Politics, Markets and America's Schools"

C-SPAN (Susan Swain and others), "C-SPAN as a Tool for Teachers and Congress"

German Embassy, an evening that included dinner and remarks by host Fritjof van Nordenskjoeld, Deputy Ambassador and Charge d'Affaires

Health Policy Briefing, by Robert Wood Johnson Congressional Fellows Richard L. Bucciarelli, M.D., Louis H. Diamond, M.D., Susan Bartlett Foote, JD, and
Barbara Ross-Lee, D.O., "Health Care Financing Proposals on the Hill"

Indonesian Embassy, with His Excellency Abdul Rachman Ramby, Ambassador of the Republic of Indonesia and others; an evening of dinner and briefing by the Ambassador, followed by cultural demonstrations and music

Mount Vernon Trip, a Potomac River cruise to Mount Vernon for a guided tour of the estate

Mary E. Radford, Judicial Fellow, a briefing on the Supreme Court, followed by attendance at oral arguments

Re-entry Panel Discussion, former Congressional Fellows brief current Fellows on potential problems encountered upon 


\section{Assignments of 1990-91 Fellows, First Half}

\section{SENATE}

Kanthi Abeyratne

Carl Allen

Norman Arseneault

Deborah G. Barger

Joseph Beck

Katya D. Bowers

Richard L. Bucciarelli

Deirdre Bumbera

Sophia Byrd

Louis H. Diamond

Susan Bartlett Foote

Donald Hester

JoAnne Alice Jackson

Karen Kedrowski

Terry Lord

Julia Monar

Peggy Overbey

Mark Peterson

Barbara Ross-Lee

Pamela L. Stephens

Martin Thunert

Joan L. Venes

Steffie Woolhandler

Donald Yamamoto

David Roy Zinzer

\section{HOUSE}

Dewi Fortuna Anwar

Cynthia M. Beck

Nick Beres

Philip Neil Caster

Daniel O. Cline

Carolyn Cocotas

Chantal B. Dalton

Timothy Dunn

Daniel P. Franklin

Michael Garrety

Micheal J. Gilbreath

Marlene Harris

Karen Henderson

Frank C. W. Lee

Ellen Meltzer

Thomas J. O'Donnell

Douglas E. Paradis

Lyn Ragsdale

Jean Shumway Warner

Martynas A. Ycas
Brock Adams (D-WA)

Charles Grassley (R-IA)

Larry E. Craig (R-ID)

Arlen Specter (R-PA)

Wyche Fowler, Jr. (D-GA)

Joseph Biden (D-DE)

John Rockefeller, IV (D-WV)

Jeff Bingaman (D-NM)

Albert Gore, Jr. (D-TN)

George J. Mitchell (D-ME)

David Durenberger (R-MN)

Frank Lautenberg (D-NJ)

Subcommittee on International Finance

and Monetary Policy (Minority Staff)

Robert Kerrey (D-NE)

Joseph Lieberman (D-CT)

Kent Conrad (D-ND)

Albert Gore, Jr. (D-TN)

Thomas A. Daschle (D-SD)

Bill Bradley (D-NJ)

Jeff Bingaman (D-NM)

Committee on Labor and Human Resources

(Edward M. Kennedy-D-MA)

John Heinz (R-PA)

Paul Wellstone (D-MN) and

Rep. Bernard Sanders (I-VT)

Daniel K. Akaka (D-HI)

Harry Reid (D-AR)

Patricia Schroeder (D-CO)

John Spratt (D-SC)

Timothy J. Penny (D-MN)

House Majority Whip (William Gray, III-D-PA)

Robert G. Torricelli (D-NJ)

Sander Levin (D-MI)

Charles B. Rangel (D-NY)

William Lehman (D-FL)

Lawrence J. Smith (D-FL)

Sander Levin (D-MI)

House Subcommittee on Arms Control

(Dante Fascell-D-FL)

Ronald V. Dellums (D-CA)

Bill Richardson (D-NM)

Michael Andrews (D-TX)

John Bryant (D-TX)

Dave McCurdy (D-OK)

Robert Lagomarsino (R-CA)

David R. Obey (D-WI)

Mary Rose Oakar (D-OH)

Jim McDermott (D-WA) returning to their professional workplaces. Participants included: Sharon Basso, Arms Control and Disarmament Agency; Kristin Huckshoren, Washington Bureau, San Jose Mercury News; Richard O. Miller, Department of the Interior; Paul Herrnson, University of Maryland, College Park; and Lisa Pullen, Department of Public Affairs, The Brookings Institution

State Department Briefing, "the Depart- ment of State and Congress," including a visit to the Secretary's office and the Operations Center

White House Briefing, at OEOB with selected members of the President's staff

Joseph Wilson IV, recently Charge d'Affaires, Baghdad, a briefing on the situation in the Middle East just prior to and during the time of Iraq's invasion of Kuwait

\section{1-92 CONGRESSIONAL} FELLOWSHIP PROGRAM

\section{Selection Committee, 1991-92}

Political Scientists and Journalists:

Milton Cummings, Jr., University of Maryland, Baltimore

Ronald D. Elving, Congressional Quarterly Weekly Report

Susan Hammond, The American University

Albert Hunt, Wall Street Journal Carol Matlack, National Journal

James A. Thurber, The American University

\section{Federal Fellows:}

Susan Adams, U.S. Department of Labor Anthony Anderson, Eckert, Seamans, Cherin and Mellott

Frederick Holborn, Paul H. Nitze School of Advanced International Studies, The Johns Hopkins University

Joseph Wilson, IV, U.S. Department of State

\section{1-92 Congressional Fellows}

\section{Political Science Fellows:}

C. Lawrence Evans, Assistant Professor of Government, The College of William \& Mary (1991-92 William A. Steiger Congressional Fellow)

William F. Grover, Assistant Professor, Department of Political Science, Saint Michael's College

Kelly D. Patterson, Assistant Professor, Department of Government, Franklin \& Marshall College

Cheryl D. Young, Visiting Assistant Professor, Department of Political Science, University of Arkansas, Fayetteville

Journalism Fellows:

Adam Gelb, Reporter, The Atlanta Journal-Constitution, Atlanta, Georgia

Heather Greenfield, Reporter, WCIV-TV, Charleston, South Carolina (1991-92 Joan Shorenstein Barone Congressional Fellow)

Claude R. Marx, Political Reporter, Arkansas Democrat, Little Rock, Arkansas (1991-92 Poynter Fellow)

Kimberly M. Shearin, Reporter, New Haven Register, New Haven, Connecticut

\section{Robert Wood Johnson}

Health Policy Fellows:

Kenneth B. Chance, D.D.S., Associate Professor of Endodontics and Assistant Dean for External Affairs and Urban Resource Development, University of Medicine and Dentistry of New Jersey, New Jersey Dental School, Newark

Robert G. Frank, Ph.D., Associate Professor and Associate Chairman, 


\section{Assignments of 1990-91 Fellows, Second Half}

\section{SENATE}

Kanthi Abeyratne

Carl Allen

Dewi Anwar

Norm Arseneault

Deborah Barger

Cindy Beck

Richard Bucciarelli

Sophia Byrd

Daniel Cline

Louis Diamond

Susan Bartlett Foote

Dan Franklin

Michael Garrety

JoAnne Jackson

Frank Lee

Terry Lord

Peggy Overbey

Douglas Paradis

Mark Peterson

Barbara Ross-Lee

Pam Stephens

Martin Thunert

Joan Venes

Don Yamamoto

Dave Zinzer

\section{HOUSE}

Joe Beck

Nick Beres

Katya Bowers

Deirdre Bumbera

Phil Caster

Carolyn Cocotas

Chantal Dalton

Timothy Dunn

Micheal Gilbreath

Marlene Harris

Karen Henderson

Donald Hester

Karen Kedrowski

Ellen Meltzer

Tim O'Donnell

Doug Paradis

Lyn Ragsdale

Jean Warner

Steffie Woolhandler

Martynas Ycas
Subcommittee on Aging (Brock Adams-D-WA)

Charles Grassley (R-IA)

Kent Conrad (D-ND)

Larry Craig (R-ID)

Arlen Specter (R-PA)

Committee on Budget Minority Staff

John Rockefeller (D-WV)

Albert Gore (D-TN)

Kent Conrad (D-ND)

George Mitchell (D-ME)

Dave Durenberger (R-MN)

Tom Harkin (D-IA)

Tom Daschle (D-SD)

International Finance and Monetary Policy

Subcommittee, Minority

Robert J. Kerrey (D-NE)

Joseph Lieberman (D-CT)

Albert Gore (D-TN)

Fank Murkowski (R-AK)

Tom Daschle (D-SD)

Bill Bradley (D-NJ)

Jeff Bingaman (D-NM)

Committee on Labor and Human Resources, Majority

Special Committee on Aging (William Cohen-R-ME)

Daniel Akaka (D-HI)

Harry Reid (D-NV)

Subcommittee on the Civil Service

Tim Penny (D-MN)

Lee Hamilton (D-IN)

Connie Morella (R-MD)

House Majority Whip (William Gray-D-PA)

Sander Levin (D-MI)

Charles Rangel (D-NY)

William Lehman (D-FL)

Subcommittee on Arms Control (Dante Fascell-D-FL)

Ron Dellums (D-CA)

William Lehman (D-FL)

John Porter (R-IL)

Sun Belt Caucus

John Bryant (D-TX)

Dave McCurdy (D-OK)

Bob Lagomarsino (R-CA)

David Obey (D-WI)

Mary Rose Oakar (D-OH)

Bernard Sanders (I-VT) and

Sen. Paul Wellstone (D-MN)

Jim McDermott (D-WA)
Department of Physical Medicine and Rehabilitation, University of Missouri School of Medicine, Columbia

Jay S. Himmelstein, M.D., M.P.H., Director, Occupational Health Program, and Associate Professor, Department of Family and Community Medicine, University of Massachusetts Medical Center, Worcester

Philip J. Hofschire, M.D., Professor, Director of Pediatric Cardiology, and Vice-Chairman for Clinical Affairs, Department of Pediatrics, University of Nebraska Medical Center, Omaha
Charles L. Rice, M.D., Surgeon-in-Chief, Harborview Medical Center, and Professor and Vice-Chairman, Department of Surgery, University of Washington School of Medicine, Seattle

Steven P. Ringel, M.D., Professor, Department of Neurology, and Director, Section of Neuromuscular Diseases, University of Colorado Health Services Center, Denver

German Fellows:

Susanne R. Frischling, Ph.D. Candidate; Master's Degree in Political Science and Public International Law, Hamburg University

Gotz-Dietrich Opitz, Master's Degree in American Culture, Political Science and Communication, LudwigMaximilian University; Head Clerk, SPD Office, Constituency of Munich

Asia Foundation Fellows:

Jackson Ke-Cheng Chang, Legislative Assistant, Legislative Yuan, Taipei, Taiwan

Hashbatyn Hulan, Full-Time Consultant, Standing Committee on Social Policy, Baga Hural, Ulan Bator, Mongolia

Thanong Khanthong, Assistant Business Editor, The Nation, Bangkok, Thailand

Maria Lourdes Y Navarro Tiquia, Research Program Officer, Congressional Research and Training Service, Quezon City, Philippines

American Anthropological

Association Fellow:

David I. Beriss, Ph.D. Candidate in French Studies/Anthropology, New York University

\section{Federal Fellows:}

David E. Balducchi, Unemployment Insurance Program Specialist, Office of Regional Management, Department of Labor

Joel H. Delofsky, Veterans' Employment Program Specialist, Office of Veterans' Employment, Reemployment and Training, Department of Labor

Claudia H. Dulmage, Attorney-Advisor, Office of Legislative Affairs, Department of Justice

Janice C. Haith, Deputy Chief, Special Security Division, Air Force Intelligence Agency, Department of the Air Force

Larry L. Hudson, Forester (Administration), United States Forest Service, Department of Agriculture

Kay C. Keely, Chief, Division of Program Development \& Implementation, Bureau of Indian Affairs, Department of the Interior

Thomas J. Klabunde, Resource Information Specialist, United States Forest Service, Department of Agriculture

Sandra K. Lindsay, Legislative Officer, National Institute on Aging, National Institutes of Health, Department of Health \& Human Services

Timothy J. Parsons, Deputy Branch Chief, National Security Agency

Rosemary B. Ramsey, Assistant Director, Division of Immunologic, Oncologic, and Hematologic Diseases, Center for Infectious Diseases, Centers for Disease Control, Department of Health \& Human Services

Myron J. Sagall, Chief, T621 (ADP and 
Telecommunications), National Security Agency

Michael A. Till, Commodity Manager, Navy Medium Caliber Gun Ammunition, Naval Weapons Support Center, Department of the Navy

Theodore A. Van Hintum, Assistant Director, Educational Operations, Education Service, Department of Veterans Affairs

Karen L. Wilson, Director of Planning, Office of Planning, Management \& Budget, Office of Justice Programs, Department of Justice

Foreign Affairs Fellows:

Donald M. Bishop, Information Officer (AIT), Taipei, United States Information Agency

Carey E. Cavanaugh, Political Officer, American Embassy, Moscow (Department of State)

Claudia N. Deverall, Staff Officer, Directorate of Operations, Central Intelligence Agency

Jessica LeCroy, Foreign Service Officer, Office of Coordinating Committee for Multilateral Strategic Export Controls, Bureau of Economic and Business Affairs (Department of State)

Malachy T. Minnies, First Secretary, American Embassy, Brasilia (Department of State)

Frank L. Prindle, Major, Executive Officer, U.S. Total Army Personnel Command, Department of the Army

Stephen K. Scroggs, Major, Executive Officer to the Chief of Staff, U.S. Forces in Korea, Department of the Army

Lisa W. Tuite, Intelligence Research Specialist-Imagery Analyst-Chief, Central Intelligence Agency

Gregory D. Vuksich, LTC, Chief of Staff, 1st Infantry Division (Forward), Department of the Army

Scott D. White, Chief, Strategic Missile Branch, Office of Scientific and Weapons Research, Central Intelligence Agency

\section{Orientation Speakers}

*The Honorable Gary Andres, Deputy Assistant to the President for Legislative Affairs, "Working for the President with Congress"

*William I. Bacchus, Senior Legislative Assistant to the Under Secretary of State for Management, "Congressional Liaison in a Time of Troubles: The State Department's Relationship with Congress"

Michael Barone, Senior Writer, U.S. News \& World Report, "Our Country: The Shaping of America from
Roosevelt to Reagan"

David Broder, The Washington Post, "The Voters' Agenda"

Colin Campbell, S.J., Isabelle and Henry Martin Chair of Philosophy and Politics, Georgetown University, "The President and Congress in an Era of Divided Government"

*Joan Claybrook, President, Public Citizen, "Lobbying for the Public Interest"

The Honorable William S. Cohen (R-ME), "Defense Issues and United States Resources"

Joseph R. Crapa, Staff Director for Representative David Obey (D-WI), "Congress, Committees and the Legislative Process"'

Roger H. Davidson, Professor of Government and Politics, University of Maryland, "The Changing Congress"

*Christopher J. Deering, Associate Dean, Columbian College, The George Washington University, "The Bicameral Congress"

The Honorable Byron Dorgan (D-ND), "World Hunger"

Peter Edelman, Associate Dean, Georgetown University Law School, and CoChairman, Americans for Peace Now, "Peace and Security in the Middle East"

Alan Ehrenhalt, Executive Editor, Governing magazine, "Why People Hate Legislatures"

Lynn Etheredge, Consultant, "History of Health Care Financing in the United States"

*Ronald D. Elving, Deputy Political Editor, Congressional Quarterly, and Barbara Vobejda, Reporter, The Washington Post, "The Impact of Demographic Changes on America's Institutions and Politics"'

Christopher H. Foreman, Jr., The American University and The Brookings Institution, "Congressional Oversight and Social Regulation"

Harrison Fox, Budget Committee Associate for The Honorable Richard J. Santorum (R-PA), "Congressional Budget Process"

William Galston, Professor, University of Maryland, and Fellow, The Woodrow Wilson International Center for Scholars, "Public Morality in a Liberal Democracy"

Susan Webb Hammond, Professor of Political Science, The American University, "Informal Congressional Groups"

Antonio Harrison, Director, Electoral Participation Project, "The Electoral Participation Project"

Karlyn H. Keene, Resident Fellow, American Enterprise Institute, and Editor, The American Enterprise, "Polls and Politics"
*George Kundanis, Executive Director, Democratic Steering and Policy Committee, "Leadership in the House"

The Honorable John Lewis (D-GA), "Civil Rights Movement in the United States"

*Thomas E. Mann, Director of Governmental Studies, The Brookings Institution, "The Democratic Opposition"

*Dana M. Marshall, Senior Advisor for International Economic Affairs to the Vice President, "The Administration's International Economic Policy"

The Honorable Abner J. Mikva, Chief Judge, U.S. Court of Appeals, D.C. Circuit, "Congress: The First Branch"

*Candice J. Nelson, Assistant Professor, The American University, "The Money Chase"

Ghia Nodia, The Institute of Philosophy of the Georgian Academy of Sciences, and Research Scholar, Kennan Institute of Advanced Russian Studies, "Strife to Independence and Perspectives of Democracy in Former Soviet Republics"

David M. O'Brien, Professor, Woodrow Wilson Department of Government and Foreign Affairs, University of Virginia, "The Supreme Court"

The Honorable David E. Price (D-NC), "From the Classroom to the Legislature"

Allen Schick, Director, Bureau of Governmental Research, School of Public Affairs, University of Maryland, "When Budgets and Elections Coincide"

Rick Shapiro, Director, Congressional Management Foundation, "Personal Offices: Member Niches, Staff Demographics and Management Problems"

Neil Skene, President, Editor and Publisher, Congressional Quarterly Weekly Report, "Our Duty to the Institutions We Cover"

*Floyd E. Stoner, Director for Legislative Operations, American Bankers Association, "Lobbying for Banking Reform"

R. Kent Weaver, Senior Fellow, The Brookings Institution, "Do Institutions Matter? Comparing Government Capabilities in the United States and Abroad"

Sharon Wolchik, Director, Russian and East European Studies, The George Washington University, "Eastern Europe"

Panel of Former Fellows:

"How to Get a Job on the Hill"

*Susan Clain, Department of Health and Human Services

*Karen Kedrowski, Legislative Analyst, Sun Belt Caucus

*Doug Paradis, Department of State

*Lisa Pullen, Department of Public 
Affairs, The Brookings Institution

Panel: "Education in America"

Michael Casserly, The Council of The Great City Schools

*Paul T. Hill, Director of Research and Analysis, RAND

Lynn C. Selmser, Professional Staff Member, House Committee on Education and Labor (Minority)

*Thomas Wolanin, Staff Director, House Subcommittee on Postsecondary Education (Rep. William D. Ford, D-MI, Chairman)

\section{CRS Legislative Institute Seminar on}

Resources and Congressional Operations:

Nancy Davenport, Associate Director for Special Programs

* Stanley Bach, Senior Specialist in American National Government

Rick Beth, Specialist in American National Government

Daniel Mulhollan, Chief, Government Division, and Senior Specialist, American National Government

Ilona Nickles, Analyst in American National Government

Judy Schneider, Specialist on the Congress

Susan Veccia, Specialist, Automated Information Resources

*Indicates former Congressional Fellow

\section{PS Index of Authored Articles}

VOLUME XXIV, NO. 1 (MARCH) THROUGH NO. 4 (DECEMBER) 1991

\section{Alphabetical Index by Author}

Agyeman, Opoku. The U.S. Supreme Court and the Enforcement of African American Rights: Myth and Reality. December, p. 679.

Alger, Dean E. Schizophrenia: The Media and the Incumbent Reelection Issue. June, p. 188

Almond, Gabriel A. Capitalism and Democracy. September, p. 467.

Altschuler, Bruce E. Lyndon Johnson: Campaign Innovator? March, p. 42.

Anderson, Teresa. What Did We Know and When Did We Know It? GAO's Role in Analysis of the Savings and Loan Crisis. September, p. 447.

Atwater, Thomas. Critical Thinking in Basic U.S. Government Classes. June, p. 209.

Avalos, Manuel. The Status of Latinos in the Profession: Problems in Recruitment and Retention. June, p. 241.
Axelrod, Robert. Building a Strong Legislature: The Western Experience. September, p. 474.

Barrett, David M. Doing "Tuesday Lunch" at Lyndon Johnson's White House: New Archival Evidence on Vietnam Decisionmaking. December, p. 676.

Bates, Robert $\mathrm{H}$. The Economics of Transitions to Democracy. March, $\mathbf{p .}$ 24.

Baumer, Donald C. An Update on the Senate Democratic Policy Committee. June, p. 174.

Bennett, Douglas C. Political Science Within the Liberal Arts: Toward Renewal of Our Commitment. June, p. 201.

Boster, Ronald S. Not on My Watch. September, p. 433.

Brady, David. Report of the Treasurer. December, p. 774.

Brintnall, Michael. Where Do Political Scientists Teach: The Distribution of the Professoriate. June, p. 258.

Brintnall, Michael. Organized Sections: A Status Report. September, p. 559.

Brintnall, Michael. The Political Science Professoriate: A Report on the Profession. March, p. 81.

Brintnall, Michael and Shelley Sallee. National Research Council Survey Highlights 1989 Doctoral Recipients in Political Science and Other Social Science Fields. June, p. 262.

Brintnall, Michael. Political Science and the Savings and Loan Crisis: An Introduction. September, p. 432.

Burke, John Francis. The Extra Credit Project: Turning a Bane into a Blessing. June, p. 220.

Clignet, Remi. Can American Social Science Majors Acquire an International Perspective? June, p. 231.

Cohen, Mel. Making Classroom Participation a Reality. December, p. 699.

Collins, Edward Jr., and Martin A. Rogoff. The Use of an Interscholastic Moot Court Competition in the Teaching of International Law. September, p. 516.

Crewe, Ivor, and Pippa Norris. British and American Evaluation: Divergence or Convergence? September, p. 524 .

Cronin, Thomas E. On Celebrating College Teaching. September, p. 482.

Crotty, William. The Political Scientist as Comparative Election Observer. March, p. 64.

DiIulio, John J. Jr. James Q. Wilson and Civic Virtue. December, p. 748.

Disch, Lisa. Toward a Feminist Conception of Politics. September, p. 501.

Eksterowicz, Anthony J. and Paul C. Cline. Ratification of the Constitution: The Great Debate as Portrayed in American Government Textbooks. June, p. 211.

Fiorina, Morris P. Divided Government in the States. December, p. 646.

Fishman, Ethan. Political Philosophy and the Policy Studies Organization. December, p. 720.

Fukuyama, Francis. Liberal Democracy as a Global Phenomenon. December, p. 659.

Grafton, Carl and Anne Permaloff. Inexpensive Database Management Software and Quicknotes. June, p. 226.

Grafton, Carl and Anne Permaloff. Hypertext and Hypermedia. December, p. 724.

Gruberg, Martin. Participation by Women in the 1991 Annual Meeting. December, p. 763.

Guliuzza, Frank III. In-Class Debating in Public Law Classes as a Complement to the Socratic Method. December, $p$. 703.

Gurr, Ted Robert. America as a Model for the World? A Skeptical View. December, p. 664.

Haas, Michael. Why a Political Film Society? March, p. 70.

Harman, John D. Running the Good Race, Part 1: High Anxiety: Some Lessons for Graduate Students Entering the Profession. September, p. 535.

Hauck, Robert J-P. From the Editor. March, p. 4.

Hill, Leslie I. Power and Citizenship in a Democratic Society. September, p. 495.

Hoefler, James M. Advertising on Cable Television in Presidential Primaries: Something to Look for in '92. March, p. 45.

Jacobson, Gary C. Explaining Divided Government: Why Can't the Republicans Win the House? December, $p$. 640.

Jenkins-Smith, Hank C. Alternative Theories of the Policy Process: Reflections on Research Strategy for the Study of Nuclear Waste Policy. June, p. 157.

Juarez, Carlos E. Recruiting Minority Students for Academic Careers: The Role of Graduate Student and Faculty Mentors. September, p. 539.

Julian, Frank H., Don H. Chamberlain, and Robert Seay. A National Status Report on Outcomes and Assessment by Departments of Political Science. June, p. 205.

Karz, Roger. The Original Washington. December, p. 705.

Kaufman-Osborn, Timothy V. From the Science to the Art of Politics. June, p. 204.

Kettl, Donald F. The Savings-and-Loan Bailout: The Mismatch Between the Headlines and the Issues. September, p. 441 .

Kilcoyne, Paula. Handling Harassment By a Student. June, p. 240.

Koch, Nadine S. Winning Is Not the 